\title{
Analisis Hubungan Berbagai Indeks Obesitas dengan Kadar Interleukin-6 pada Subjek Obesitas dan Non Obesitas Sentral
}

Association Between Obesity Indices and Interleukin-6 Levels in Subjects with Central and Non-Central Obesity

\author{
Asni R Tina ${ }^{1 *}$, Liong B Kurniawan ${ }^{1,2}$, Uleng Bahrun ${ }^{1,2}$ \\ ${ }^{1}$ Program Pascasarjana Ilmu Biomedik, Sekolah Pascasarjana Universitas Hasanuddin \\ ${ }^{2}$ Departemen Patologi Klinik, Fakultas Kedokteran, Universitas Hasanuddin \\ Jl. Perintis Kemerdekaan No. KM. 10, Makassar, Sulawesi Selatan, Indonesia \\ *Penulis korespondensi \\ Email: asniaksioma@gmail.com
}

Received: March 9, 2021

Accepted: August 1, 2021

\begin{abstract}
Abstrak
Obesitas sentral adalah penumpukan lemak pada tubuh bagian abdomen yang diakibatkan oleh jumlah lemak berlebih. Interleukin-6 merupakan sitokin yang diekskresi oleh jaringan adiposa dan kadarnya meningkat pada obesitas sentral. Tujuan penelitian ini adalah menganalisis hubungan indeks obesitas dengan kadar interleukin-6 pada obesitas sentral serta non obesitas sentral. Responden dalam penelitian berjumlah 75 subjek yang di antaranya 20 subjek laki-laki dan 20 subjek perempuan obesitas sentral serta 20 subjek laki-laki dan 15 subjek perempuan non obesitas sentral. Metode yang digunakan dalam penelitian ini adalah observasional. Hasil penelitian menunjukkan terdapat perbedaan bermakna antara indeks massa tubuh $(p<0,001)$, lingkar pinggang $(p<0,001)$, lemak tubuh $(p=0,003)$ dan lemak viseral $(p<0,001)$ subjek obesitas sentral dengan obesitas non sentral. Hasil penelitian juga membuktikan bahwa Indeks Massa Tubuh (IMT), Lingkar Pinggang (LP), lemak tubuh dan lemak viseral tidak berkorelasi dengan IL-6 pada subjek laki-laki dan pada subjek perempuan hanya lemak viseral yang berkorelasi dengan IL-6 ( $p=0,043 ; r=0,343)$. Simpulan penelitian, terdapat korelasi signifikan antara lemak viseral dan kadar IL-6 pada subjek perempuan obesitas sentral dan non obesitas sentral.
\end{abstract}

Kata kunci: obesitas sentral; lemak viseral; lemak tubuh; interleukin-6

\begin{abstract}
Central obesity can be described as an accumulation of fat in the body which is located in the abdomen and it occurs due to excess amount of fat. Interleukin-6 is a cytokine that is excreted by adipose tissue and its levels are increased in central obesity. This study aimed to analyze the relationship between the obesity index and IL-6 levels on central obesity and noncentral obesity. The number of respondents involved in this study was 75 subjects, divided into 20 male subjects and 20 female subjects who are suffering from central obesity and 20 male subjects and 15 female subjects who are free from central obesity. Data were collected using the observational method. The results of the analysis revealed that there were some significant differences in body mass index ( $p<0.001)$, waist circumference $(p<0.001)$, body fat $(p=0.003)$, and visceral fat $(p<0.001)$ between central obesity and non-central obesity subjects. The results also depicted that Body Mass Index (BMI), Waist Circumference (WC), body fat, and visceral fat
\end{abstract}




\section{Research Article}

did not correlate with IL-6 on male subjects, and there was only visceral fat correlated with IL-6 ( $p=0.043 ; r=0.343)$ on female subjects. In conclusion, there was a significant correlation between visceral fat and IL-6 levels on female subjects with central obesity and non-central obesity.

Keywords: central obesity; visceral fat; body fat; interleukin-6

\section{Pendahuluan}

Obesitas sentral merupakan pertanda bahaya untuk kesehatan. Obesitas sentral terjadi karena meningkatnya ukuran atau jumlah sel jaringan adiposa yang bisa mengakibatkan gangguan metabolisme. ${ }^{1}$ Prevalensi obesitas sentral di Indonesia menurut Riskesdas (2018) berdasarkan lingkar pinggang (LP) terus mengalami peningkatan. Pada tahun 2007 secara nasional angka obesitas sentral mencapai 18,8\%, di tahun 2013 meningkat mencapai 26,6\% dan pada tahun 2018 jumlahnya menjadi $31 \% .^{2}$ Sel adiposa selain menjadi lokasi penyimpanan lemak, merupakan organ yang menghasilkan molekul biologi aktif (adipokin) misal sitokin proinflamasi, hormon antiinflamasi serta subtansi biologi yang lain. Obesitas sentral mengakibatkan ekspresi sitokin proinflamasi meningkat dalam sirkulasi alhasil menyebabkan inflamasi dinding vaskuler. ${ }^{3,4}$ Telah diketahui bahwa obesitas merupakan suatu inflamasi sistemik dan kronik, terutama pada White Adipose Tissue yang ditandai oleh peningkatan kadar sitokin proinflamasi dalam sirkulasi seperti Interleukin-6 (IL-6) dan Tumor Necrosis Factor- $\alpha$ (TNF- $\alpha)^{4,5}$

Interleukin-6 dapat menginduksi produksi TNF- $\alpha$ dan memperantarai reaksi inflamasi in vitro. ${ }^{6}$ Penelitian yang dilakukan Rahmawati tahun 2014 menunjukkan bahwa jaringan adiposa menghasilkan 25\% IL-6 sistemik. Jaringan adiposa ini bisa mengakibatkan inflamasi sistemik tingkat rendah pada orang dengan kelebihan lemak tubuh. Interleukin-6 merupakan stimulator produksi oksigen reaktif dan nitrogen oleh makrofag juga monosit. ${ }^{7}$

Pengukuran indeks obesitas pada obesitas sentral umumnya dilakukan untuk melihat prediksi gangguan metabolik. Sejumlah penelitian mengemukakan jika indeks obesitas misal indeks masa tubuh (IMT), LP, lemak tubuh dan lemak viseral berkaitan terhadap sindrom metabolik, tetapi sejumlah penelitian mendapatkan hasil yang tidak konsisten. Terdapat korelasi yang kuat antara indeks obesitas terhadap gangguan metabolik yang dipengaruhi oleh sejumlah faktor di antaranya adalah umur, jenis kelamin, ras, etnik serta genetik. ${ }^{8,9}$

Telah diketahui bahwa obesitas berkorelasi kuat dengan aterosklerosis dan penyakit kardiovaskular yang menyebabkan kematian di banyak negara termasuk Indonesia. Penelitian ini 


\section{Research Article}

bertujuan untuk menganalisis bagaimana hubungan indeks obesitas dengan kadar IL-6 pada subjek dengan obesitas sentral dan non obesitas sentral.

\section{Metode}

Desain penelitian yang digunakan dalam penelitian ini adalah observasional dengan pendekatan potong lintang (Cross Sectional). Penelitian dilakukan pada bulan Agustus hingga Desember 2020 menggunakan sampel serum darah di Laboratorium Patologi Klinik dan Unit Penelitian Fakultas Kedokteran Universitas Hasanuddin (FKUH) / RSPTN Universitas Hasanuddin. Populasi dalam penelitian ini adalah masyarakat dengan subjek obesitas sentral yang mempunyai kriteria LP laki-laki $\geq 90 \mathrm{~cm}$ serta perempuan $\geq 80 \mathrm{~cm}$ serta subjek non obesitas sentral dengan LP laki-laki $<90 \mathrm{~cm}$ dan perempuan $<80 \mathrm{~cm}$. Jumlah sampel pada penelitian ini adalah 75 sampel yang terbagi atas 20 subjek laki-laki dan 20 subjek perempuan dengan obesitas sentral, serta 20 subjek laki-laki dan 15 subjek perempuan non obesitas sentral. Kriteria inklusi dalam penelitian ini adalah laki-laki dan perempuan umur 18-40 tahun. Kriteria eksklusi pada penelitian ini adalah subjek menderita diabetes melitus atau hipertensi.

Prosedur penelitian dimulai dengan pemberian penjelasan dan informed consent oleh peneliti kepada subjek penelitian. Selanjutnya dilakukan pengukuran indeks obesitas IMT, LP, lemak tubuh dan lemak viseral menggunakan alat Bioelectrical Impedance Analysis (BIA) merek TANITA BC-541. Pengambilan sampel darah dilakukan oleh petugas Laboratorium Patologi Klinik selanjutnya sampel dibawa ke laboratorium untuk dilakukan pemeriksaan glukosa darah dan kadar IL-6. Kadar glukosa darah diperiksa menggunakan alat Clinical Chemistry Analyzer ABX Pentra 400. Pemeriksaan kadar IL-6 menggunakan metode ELISA (Enzyme-Linked Immunosorbent Assay) kit Human Interleukin-6 (Bioassay Technology Laboratory/ Shanghai), satuan dinyatakan dalam ng/L. ${ }^{10}$ Responden yang memiliki kadar glukosa darah tinggi (> 126 $\mathrm{mg} / \mathrm{dl})$ dieliminasi dari penelitian.

Hasil penelitian diolah memakai program Statistical Product and Service Solutions (SPSS 22.0) for Windows. Analisis hasil indeks obesitas yang terdiri dari IMT, LP, lemak tubuh, lemak viseral dan kadar IL-6 memakai Independent T test dan Mann Whitney Test untuk mengetahui perbedaan masing-masing indeks obesitas dan kadar IL-6 pada subjek obesitas sentral dan subjek non obesitas sentral. Selanjutnya dilakukan analisis hubungan antara indeks obesitas dan kadar IL-6 menggunakan uji korelasi Spearman. Penelitian ini sudah memperoleh persetujuan Komisi Etik Penelitian Kesehatan (KEPK) Fakultas Kedokteran Universitas Hasanuddin-RSPTN Universitas Hasanuddin, Makassar Nomor: 700/UN4.6.4.5.31/ PP36/ 2020. 


\section{Research Article}

\section{Hasil}

Data penelitian ini adalah data primer yang didapat dengan cara pengambilan data langsung. Uji normalitas data dengan Kolmogrof smirnov menunjukkan variabel umur, tinggi badan (TB) dan lemak tubuh terdistribusi normal, sedangkan variabel berat badan (BB), IMT, LP, lemak viseral dan IL-6 tidak terdistribusi normal.

Gambaran subjek penelitian secara umum dan jumlah subjek laki-laki serta perempuan pada penelitian ini bisa dilihat dalam Tabel 1. Subjek pada penelitian ini memiliki rentang umur 21 tahun sampai 39 tahun.

Tabel 1 Karakteristik Subjek Penelitian

\begin{tabular}{|c|c|c|c|}
\hline Variabel & $\begin{array}{c}n=75 \\
(100 \%)\end{array}$ & Mean \pm SD & Median (Min-maks) \\
\hline Umur (tahun) & & $30,47 \pm 4,53$ & $31,00(21,00-39,00)$ \\
\hline \multicolumn{4}{|l|}{ Jenis Kelamin: } \\
\hline Laki-laki & 40 & - & - \\
\hline Perempuan & 35 & & \\
\hline \multicolumn{4}{|l|}{ Kelompok: } \\
\hline \multicolumn{4}{|l|}{ Obesitas sentral: } \\
\hline laki-laki & 20 & - & - \\
\hline perempuan & 20 & & \\
\hline \multicolumn{4}{|l|}{ Non Obesitas sentral } \\
\hline Laki-laki & 20 & & \\
\hline perempuan & 15 & & \\
\hline $\mathrm{BB}(\mathrm{kg})$ & - & $70,71 \pm 17,38$ & $67,20(47,10-137,60)$ \\
\hline $\mathrm{TB}(\mathrm{cm})$ & - & $162,39 \pm 0,08$ & $162,00(149,00-184,00)$ \\
\hline IMT (kg/m2) & - & $26,70 \pm 5,57$ & $25,28(19,73-47,61)$ \\
\hline $\mathrm{LP}(\mathrm{cm})$ & - & $87,50 \pm 12,59$ & $85,00(68,00-136,50$ \\
\hline Persen lemak tubuh $(\%)$ & - & $32,06 \pm 8,29$ & $32,90(11,50-49,70)$ \\
\hline Lemak viseral (Unit) & - & $12,15 \pm 7,82$ & $10,00(2,00-30,00)$ \\
\hline Kadar IL-6 (ng/L) & - & $106,24 \pm 25,96$ & $101,00(55,00-174,00)$ \\
\hline
\end{tabular}

Terdapat perbedaan IMT $(p=<0,001), \operatorname{LP}(p=<0,001)$, persen lemak tubuh $(p=0,010)$, serta lemak viseral $(p=<0,001)$ pada subjek laki-laki obesitas sentral dan non obesitas sentral. 


\section{Research Article}

Perbedaan berbagai indeks obesitas antara subjek laki-laki obesitas sentral dan non obesitas sentral dapat dilihat pada Tabel 2.

Tabel 2 Perbedaan Indeks Obesitas pada Subjek Laki-Laki dengan Obesitas Sentral dan Non Obesitas Sentral

\begin{tabular}{lccc}
\hline \multirow{2}{*}{ Variabel } & Obesitas sentral & Non obesitas sentral & \\
\cline { 2 - 3 } & Mean $\pm \mathrm{SD}$ & Mean $\pm \mathrm{SD}$ & $p$ \\
\hline IMT $\left(\mathrm{Kg} / \mathrm{m}^{2}\right)$ & $30,70 \pm 5,77$ & $23,18 \pm 2,18$ & $*{ }^{*}<0,001$ \\
LP $(\mathrm{cm})$ & $102,52 \pm 10,47$ & $83,00 \pm 4,02$ & ${ }^{*}<0,001$ \\
Lemak tubuh $(\%)$ & $38,23 \pm 7,00$ & $31,13 \pm 9,01$ & ${ }^{*} 0,010$ \\
Lemak viseral (unit) & $20,20 \pm 7,39$ & $9,90 \pm 4,88$ & $*{ }^{*}<0,001$ \\
\hline
\end{tabular}

Sumber : Data Primer

Keterangan $:$ Mean $=$ Rata-rata, Min $=$ Minimal, Max $=$ Maksimal, $\mathrm{SD}=$ Standar deviasi, $\mathrm{IMT}=$ Indeks massa tubuh, $\mathrm{LP}=$ Lingkar pinggang, IL- $6=$ Interleukin- $6, p=$ Probabilitas

*Uji Mann Whitney

**Uji Independent T test

Perbedaan bermakna juga ditemukan pada IMT $(p=<0,001)$, LP $(p=<0,001)$, persen lemak tubuh $(p=0,032)$ dan lemak viseral $(p=<0,001)$ pada subjek perempuan obesitas sentral dan non obesitas sentral. Perbedaan berbagai indeks obesitas antara subjek laki-laki obesitas sentral dan non obesitas sentral dapat dilihat pada Tabel 3.

Tabel 3 Perbedaan Indeks Obesitas pada Subjek Perempuan dengan Obesitas Sentral dan Non Obesitas Sentral

\begin{tabular}{lccc}
\hline \multirow{2}{*}{ Variabel } & Obesitas sentral & Non obesitas sentral & \\
\cline { 2 - 3 } & Mean $\pm \mathrm{SD}$ & Mean $\pm \mathrm{SD}$ & $p$ \\
\hline IMT $\left(\mathrm{Kg} / \mathrm{m}^{2}\right)$ & $29,06 \pm 5,75$ & $22,89 \pm 1,89$ & ${ }^{*}<0,001$ \\
LP $(\mathrm{cm})$ & $88,20 \pm 6,82$ & $72,53 \pm 3,36$ & ${ }^{* *}<0,001$ \\
Lemak tubuh $(\%)$ & $31,15 \pm 6,45$ & $26,30 \pm 6,17$ & ${ }^{* *} 0,032$ \\
Lemak viseral (unit) & $12,05 \pm 6,20$ & $4,53 \pm 1,50$ & $*{ }^{*}<0,001$ \\
\hline
\end{tabular}

Sumber : Data Primer

Keterangan $:$ Mean $=$ Rata-rata, Min $=$ Minimal, Max $=$ Maksimal, $\mathrm{SD}=$ Standar deviasi, $\mathrm{IMT}=$ Indeks massa tubuh, $\mathrm{LP}=$ Lingkar pinggang, IL- $6=$ Interleukin- $6, p=$ Probabilitas

* Uji Mann Whitney

**Uji Independent T test

Hasil uji statistik memakai uji Mann Whitney (variabel IL-6 tidak berdistribusi normal) menunjukkan tidak ada perbedaan bermakna antara laki-laki obesitas sentral dan laki-laki non obesitas sentral $(p=0,433)$. Kadar IL-6 pada subjek perempuan obesitas sentral dan non obesitas sentral menunjukkan perbedaan yang berarti dengan nilai $p=0,017$. Rerata kadar IL-6 pada subjek perempuan obesitas sentral adalah 115,60 ng/L, sedangkan rerata kadar IL-6 pada subjek 


\section{Research Article}

non obesitas sentral yaitu 96,07 ng/L. Perbedaan kadar IL-6 pada laki-laki dan perempuan subjek obesitas sentral dan non obesitas sentral dapat dilihat pada Tabel 4.

Tabel 4 Perbedaan Kadar Interleukin-6 pada Subjek Laki- Laki dan Perempuan Obesitas Sentral dan Non Obesitas Sentral

\begin{tabular}{|c|c|c|c|c|}
\hline \multirow{2}{*}{\multicolumn{2}{|c|}{ Jenis Kelamin }} & \multicolumn{2}{|c|}{ IL-6 (ng/L) } & \multirow[t]{2}{*}{$p$} \\
\hline & & Mean $\pm S D$ & Min-Max & \\
\hline Laki-Laki & $\begin{array}{l}\text { Obesitas Sentral } \\
(20) \\
\text { Non Obesitas } \\
\text { Sentral (20) }\end{array}$ & $\begin{array}{l}105,10 \pm 31,37 \\
105,65 \pm 23,70\end{array}$ & $\begin{array}{l}63,00-174,00 \\
68,00-142,00\end{array}$ & ${ }^{*} 0,433$ \\
\hline Perempuan & $\begin{array}{l}\text { Obesitas Sentral } \\
(20) \\
\text { Non Obesitas } \\
\text { Sentral (15) }\end{array}$ & $\begin{array}{l}115,60 \pm 24,84 \\
96,07 \pm 19,70\end{array}$ & $\begin{array}{l}76,00-159,00 \\
55,00-123,00\end{array}$ & ${ }^{* * *} 0,017$ \\
\hline
\end{tabular}

Keterangan $:$ Mean $=$ rata-rata, Min $=$ minimal, Max $=$ Maksimal, $\mathrm{SD}=$ Standar deviasi, IL-6 = Interleukin-6, $p=$ Probabilitas *Uji Mann Whitney

**Uji Independent T test

Korelasi berbagai pengukuran antropometri terhadap kadar IL-6 pada subjek pria serta wanita pada Tabel 5. Hasil analisis lanjutan menunjukkan korelasi yang bermakna $(\mathrm{r}=0,343 ; p=$ 0,043 ) antara lemak viseral dengan kadar IL-6 pada subjek perempuan.

Tabel 5 Korelasi Indeks Obesitas dengan Kadar Interleukin-6 Pada Subjek Laki-Laki dan Perempuan

\begin{tabular}{cccc}
\hline \multirow{2}{*}{ Antropometri } & & \multicolumn{2}{c}{ Kadar IL-6 $(\mathrm{ng} / \mathrm{L})$} \\
\cline { 3 - 4 } IMT $\left(\mathrm{kg} / \mathrm{m}^{2}\right)$ & $p$ & Laki-laki & Perempuan \\
& $\mathrm{r}$ & $-0,190$ & 0,121 \\
& $p$ & 0,392 & 0,267 \\
LP $(\mathrm{cm})$ & $\mathrm{r}$ & $-0,139$ & 0,120 \\
& $\mathrm{r}$ & 0,551 & 0,268 \\
Lemak tubuh & $p$ & $-0,097$ & 0,738 \\
$(\%)$ & $\mathrm{r}$ & 0,674 & 0,059 \\
Lemak Viseral & $p$ & $-0,069$ & $\mathbf{0 , 0 4 3}$ \\
$($ unit) & $\mathrm{r}$ & & $\mathbf{0 , 3 4 3}$ \\
\hline
\end{tabular}

Sumber : Data Primer

Keterangan : $\mathrm{P}=$ probabilitas, $\mathrm{r}=$ koefisien korelasi

Uji Korelasi Spearman's 


\section{Research Article}

\section{Diskusi}

Pada individu normal jaringan adiposa hanya mensekresikan sedikit interleukin-6 (IL-6). Korelasi antara IL-6 dan obesitas sentral ditandai dengan adanya peningkatan jaringan adiposa dan peran IL-6 dalam sistem imunitas tubuh. Terjadi perubahan berat dan struktur jaringan adiposa disebabkan pengaruh sintesis lipid dan protein yang meningkat. Peningkatan jaringan adiposa juga dipengaruhi oleh peningkatan asam lemak bebas dan infiltrasi makrofag ke jaringan adiposa. ${ }^{8,11}$

Hal ini sesuai dengan temuan eksperimental bahwa IL-6 bertindak sebagai stimulator poten produksi oksigen reaktif serta nitrogen oleh makrofag juga monosit. Inflamasi merupakan manifestasi dari peningkatan stres oksidatif yang meningkat pada seseorang dengan obesitas sentral. Mekanisme inflamasi pada obesitas sentral berhubungan dengan jaringan adiposa yang menghasilkan adipokin serta protein fase akut yang disebabkan oleh hipoksia serta akan diproduksi berlebih pada obesitas sentral. ${ }^{12,13,14}$

Eksperimen in vitro menunjukkan bahwa permulaan proses inflamasi sebagai respons terhadap kelebihan nutrisi terjadi di jaringan adiposa. Penelitian menunjukkan akumulasi lipid menyebabkan peningkatan ekspresi gen yang mengkode sitokin, kemokin dan molekul adhesi dalam adiposit, menarik sel imun masuk, dan berkontribusi pada sintesis mediator proinflamasi. Jaringan adiposa menghasilkan sebanyak 25\% IL-6 sistemik sehingga jaringan adiposa bisa mengakibatkan inflamasi sistemik tingkat rendah. ${ }^{15}$

Ekspresi IL-6 meningkat pada jaringan adiposa subjek obesitas sentral dibandingkan dengan jaringan adiposa pada subjek non obesitas sentral. Interleukin-6 merupakan sitokin multifungsi yang disekresikan oleh banyak jenis sel, terutama sel T, makrofag, sel endotel, sel otot polos, adiposit, dan hepatosit. Interleukin-6 juga mengatur produksi sel molekul adhesi, mediator kemotaktik dan protein fase akut, serta menjadi mediasi pelepasan sitokin lain yang memperkuat respons inflamasi. Mekanisme kerja IL-6 dikodefikasi oleh gen yang terletak dikromosom 7p21. $5,7,16$

Semua indeks obesitas tidak berkorelasi dengan IL-6 pada subjek laki-laki (semua variabel mempunyai nilai $p$ lebih besar dari 0,05 ). Hanya lemak viseral yang berkorelasi dengan kadar IL-6 $(\mathrm{r}=0,343 ; p=0,043)$ pada subjek perempuan. Hal ini tidak sama dengan penelitian Schlecht et al. tahun 2016 yang mendapatkan hubungan positif moderat pada lemak viseral dan IMT dengan IL-6 $(r=0.470 ; p=0.010$ dan $r=0.360 ; p=0.049)$ pada populasi laki-laki. Pada penelitian tersebut hubungan antara lemak viseral dan IL-6 lebih kuat dibandingkan antara IMT 


\section{Research Article}

dan IL-6, sehingga disimpulkan lemak viseral merupakan indikator terkuat dalam peningkatan kadar IL-6. ${ }^{8}$

Hal ini mungkin disebabkan peningkatan produksi estrogen di jaringan adiposa dan berbanding lurus dengan peningkatan regulasi ekspresi gen pro-inflamasi pada perempuan. Lemak viseral pada laki-laki berkisar antara 10-20\% lemak total dan pada perempuan 5-8\%. Jumlah ini meningkat bersamaan dengan usia. Lemak tubuh laki-laki berkisar antara 18-23\% dan perempuan berkisar antara 25-30\%. Laki-laki telah terbukti memiliki lebih banyak lemak viseral dan lebih sedikit lemak tubuh dibandingkan perempuan. Namun meskipun demikian, lemak viseral tetap menjadi prediktor signifikan dari kadar IL-6 di semua kelompok analisis tersebut. ${ }^{16}$ Penelitian Muvais tahun 2015 menemukan bukti bahwa peningkatan volume jaringan adiposa viseral dan jaringan adiposa subkutan secara konsisten dan lebih kuat terkait dengan faktor risiko yang lebih merugikan pada perempuan dibandingkan pada laki-laki. ${ }^{18}$

Terdapat pengaruh perbedaan jenis kelamin dalam hemeostasis metabolik di jaringan somatik. Perempuan cenderung menolak hilangnya simpanan energi tubuh, sedangkan laki-laki cenderung untuk segera memobilisasi simpanan energi. Saat istirahat dan selama keadaan pasca absorpsi, perempuan mengubah free fatty acid (FFA) menjadi trigliserida yang membantu menyimpan lemak. ${ }^{18}$

Lemak viseral mempunyai reseptor glukokortikoid serta androgen lebih banyak, memiliki metabolisme yang lebih aktif, yaitu lebih sensitif terhadap lipolisis serta lebih resisten insulin. Jaringan adiposa viseral mempunyai kemampuan lebih besar menghasilkan FFA, meningkatkan glukosa serta lebih sensitif terhadap stimulasi adrenergik. ${ }^{19}$ Lemak viseral banyak mengandung adiposit besar yang bersifat resisten insulin. Kondisi ini mencegah glukosa masuk ke dalam sel dan mengakibatkan banyak lemak yang masuk ke dalam sel, sehingga oksidasi lemak juga meningkat pada subjek obesitas sentral. lemak viseral memiliki aktivitas lipolisis yang lebih besar dan lebih rentan terhadap induksi katekolamin dibandingkan kegiatan antilipolisis oleh insulin. ${ }^{20}$

Peningkatan kadar FFA pada adiposit besar memberikan stimulasi makrofag yang telah ada untuk menghasilkan TNF- $\alpha$. Asam lemak bebas jenuh berikatan dengan toll like receptor- 4 (TLR-4) yang diekspresikan oleh makrofag dan mengaktivasi nuclear factor kappa-B cell (NFkB). Tumor necrosis factor- $\alpha$ yang dihasilkan makrofag mengaktivasi adiposit sehingga meningkatkan ekspresi berbagai gen yang di antaranya IL-6. Kadar adiponektin yang rendah menguatkan lingkaran ini dengan mengurangi penghambatan TLR-4 dalam mengaktivasi NFkB. ${ }^{11,13,16}$ 


\section{Research Article}

Estrogen mempengaruhi proses imun dan inflamasi yang dibuktikan oleh peningkatan kadarnya terhadap infeksi dan penyakit non infeksi, sebagai respons inflamasi yang lebih tinggi pada perempuan daripada dengan laki-laki yang disebabkan oleh siklus menstruasi, kehamilan dan menopause. Relevansi estrogen dengan inflamasi pada obesitas sentral adalah peran estrogen dalam mempengaruhi aktivitas NF-kB yang mengatur berbagai gen proinflamasi melalui mekanisme genomik dan non genomik. Di sisi lain, estrogen juga mempunyai efek perlindungan yang didasarkan hasil penelitian bahwa perempuan pra-menopause kurang rentan dalam perkembangan penyakit kardiovaskuler dibandingkan perempuan pasca-menopause yang tingkat estrogennya rendah. ${ }^{21}$

Tidak adanya hubungan bermakna IMT, LP dan lemak tubuh terhadap kadar IL-6 dapat diakibatkan oleh subjek penelitian yang memiliki rentang umur lebih sempit (21-39 tahun) sehingga kadar IL-6 belum meningkat jika dibandingkan dengan penelitian Schlect et al. tahun 2016 yang memiliki rentang umur 22-69 tahun. ${ }^{8}$ Hipotesis yang bisa diajukan pada penelitian ini yaitu jika pada subjek dewasa muda masih terdapat mekanisme kompensasi yang lebih baik, dibandingkan pada subjek dewasa dengan umur yang lebih tua, kadar IL-6 akan meningkat seiring terjadinya penuaan. Meskipun tidak ditemukan perbedaan bermakna kadar IL-6 pada subjek lakilaki obesitas sentral dan non obesitas sentral, tetapi hal ini belum bisa menggambarkan bahwa tidak terjadi komplikasi aterosklerosis yang berdampak pada kejadian cardiovascular disease (CVD) melalui proses aterogenesis yang diperantarai oleh IL-6 pada penderita obesitas sentral.

Pada penelitian ini kadar IL-6 lebih tinggi secara bermakna pada subjek perempuan dengan obesitas sentral dibandingkan subjek non obesitas sentral. Lemak viseral juga menunjukkan korelasi positif secara signifikan dengan kekuatan lemah terhadap kadar IL-6 pada subjek perempuan.

Penelitian ini memiliki beberapa keterbatasan. Pertama, desain penelitian cross sectional yang digunakan tidak dapat menjelaskan kausalitas hasil penelitian. Ke-dua, jumlah responden yang tidak sama antara subjek obesitas sentral dan non obesitas sentral pada subjek perempuan. Ke-tiga, alat yang digunakan oleh peneliti untuk mengukur nilai persen lemak tubuh dan lemak viseral adalah alat sederhana BIA (Bioelectrical Impedance Analysis). Ke-empat, faktor-faktor yang dapat mempengaruhi risiko kardiovaskuler tidak dianalisis. Ke-lima, biomarker lain seperti trigliserida, kolesterol LDL dan kolesterol HDL tidak diperhitungkan dalam penelitian ini. Penelitian selanjutnya diharapkan dapat menggunakan MRI (Magnetic Resonance Imaging) untuk mengukur persen lemak tubuh dan lemak viseral sehingga hasil yang didapatkan lebih 


\section{Research Article}

akurat. Penelitian selanjutnya diharapkan mengukur biomarker lain untuk memperkuat hasil penelitian.

\section{Simpulan}

Terdapat korelasi signifikan antara lemak viseral dan kadar IL-6 pada subjek perempuan obesitas sentral dan non obesitas sentral.

\section{Daftar Pustaka}

1. Ahmad N, Adam SIM, Nawi AM, Hassan MR, Ghazi HF. Abdominal Obesity Indicators: Waist Circumference or Waist To Hip Ratio in Malaysian Adults Population. Int J Prev Med. 2016;82(7):1-6.

2. Riskesdas. Hasil Utama Riskesdas 2018. Badan Penelitian dan Pengembangan Kesehatan Kementerian RI. Jakarta; 2018. h. 86-9.

3. Mayasari S, Sulchan M. Densitas Energi Makanan dan Lingkar Pinggang Sebagai Faktor Risiko Peningkatan Kadar C-Reactive Protein (CRP) pada Remaja Obesitas dengan Sindrom Metabolik. J Nutr Coll. 2014;3(3):3707.

4. Sanchez AF, Santillan EM, Bautista M, Soto JE, Gonzalez AM, Chirino CE et al. Inflammation, Oxidative Stress, and Obesity. IJMS.2011;12(2):3117- 32.

5. Rodrigues KF, Pietrani NT, Bosco AA, Campos FMF, Sandrim VC, Gomes KB. IL-6, TNF- $\alpha$, and IL-10 Levels/ Polymorphisms and Their Association with Type 2 Diabetes Mellitus and Obesity in Brazilian Individuals. Arch Endocrinol Metab. 2017;61(5):438-46.

6. Rose JS. IL-6 Trans-signaling via The Soluble IL-6 Receptor: Importance for The Pro-inflammatory Activities of IL-6. Int J Biol Sci. 2012;8(9):1237-47.

7. Rahmawati A. Mekanisme Terjadinya Inflamasi dan Stres Oksidatif pada Obesitas. El-Hayah. 2014;5(1):1-8

8. Schlecht I, Fischer B, Behrens G, Leitzmann MF. Relations of Visceral and Abdominal Subcutaneous Adipose Tissue, Body Mass Index, and Waist Circumference to Serum Concentrations of Parameters of Chronic Inflammation. Obes Facts. 2016;9(3):144-57.

9. Gibson RS, Bailey KB, Williams S, Houghton L, Ribeiro HCC, Mattos AP et al. Tissue Iron Deficiency and Adiposity-related Inflammation in Disadvantaged Preschoolers from NE Brazil. Eur J Clin Nutr. 2014;68(8):88791.

10. Zhou YQ, Liu Z, Liu ZH, Chen SP, Li M, Shahveranov A et al. Interleukin-6: an Emerging Regulator of Pathological Pain. J Neuroinfl. 2016;13(1):1-9.

11. Karkhur S, Hasanreisoglu M, Vigil E, Halim MS, Hassan M, Plaza C et al. Interleukin-6 Inhibition in The Management of Non-Infectious Uveitis and Beyond. J Ophth Infl Inf. 2019;17(9):1-14.

12. Susantiningsih T, Mustofa S. Ekspresi IL-6 dan TNF- $\alpha$ Pada Obesitas. JK Unila. 2018;2(2):174-80

13. Schaper F, Rose JS. Interleukin-6: Biology, Signaling and Strategies of Blockade. Cytokine Growth Factor Rev. 2015; 26(5):475-87.

14. Gotera W, Mahadita W, Bakta IM, Oka AAG, Budiartha AAG, Manuaba P, Maliawan S. Waist Circumference Increased Risk of Benign Prostatic Hyperplasia Through An Increase in The Level of Interleukin-6 and Insulin Resistance in Abdominal Obesity Patients. Bali Med J. 2017; 6 (1): 204-10.

15. Suganami T, Tanaka M, Ogawa Y. Adipose Tissue Inflammation and Ectopic Lipid Accumulation. Endocr J. 2012;59(10):849-57.

16. Jialal I, Kaur H, Devaraj S. Toll-like Receptor Status in Obesity and Metabolic Syndrome: A Translational Perspective. J Clin Endocrinol Metab. 2014;99(1):39-48.

17. Bloor ID, Symonds ME. Sexual Dimorphism in White and Brown Adipose Tissue with Obesity and Inflammation. Horm Behav. 2014;66(1):95-103.

18. Mauvais-Jarvis F. Sex Differences in Metabolic Homeostasis, Diabetes, and Obesity. Biol Sex Differ. 2015;6(14):1-9.

19. Halim R, Suzan R. Kadar Leptin Serum Pada Remaja Overweight Dan Obesitas. Jambi Med J. 2020;8(1):102-10.

20. Ji P, Drackley JK, Khan MJ, Loor JJ. Inflammation and Lipid metabolism-related Gene Network Expression in Visceral and Subcutaneous Adipose Depots of Holstein Cows. J Dairy Sci. 2014;97(6):3441-8.

21. Kovats S. Estrogen Receptors Regulate Innate Immune Cells and Signaling Pathways. Cell Immunol. 2015;294(2):63-9. 